\title{
HbS/D-Punjab Disease: Report of 3 Cases from Sri Lanka
}

\author{
Krishan Hewa Thalagahage ${ }^{1} \cdot$ Jayaweera Arachchige Asela Sampath Jayaweera $^{2}$ (1) \\ Widuranga Kumbukgolla ${ }^{3} \cdot$ Nilukshi Perera $^{4} \cdot$ Ela Thalagahage $^{4} \cdot$ Jayani Kariyawasam $^{5}$. \\ Vajira Dissanayake ${ }^{5,6}$
}

Received: 22 April 2017 / Accepted: 15 July 2017/Published online: 22 July 2017

(C) Indian Society of Haematology \& Transfusion Medicine 2017

Keywords HbS/D- Punjab disease · Hydroxyurea . Clinical spectrum

Double heterozygosity for sickle cell $+\mathrm{Hb}$ D-Pubjab is a rare symptomatic hemoglobinopathy arising from biallelic mutations of the HBB gene. One allele produces $\mathrm{HbS}$ while other allele is producing HbD-Punjab. p.Glu6Val mutation in HBB codes for $\mathrm{HbS}$ and p.Glu121Gln mutation codes for HbD-Punjab. [1].

Clinical manifestations of sickle cell HbSD-Pubjab exhibit slightly milder outcome compared to common sickle cell anemia (HbSS). However, Splenomegaly is more common in HbSD-Punjab than in HbSS disease [2]. Elevated blood $\mathrm{HbF}$ level is known to be protective against HbSS disease which minimizes the severity and the complications. Hydroxyurea is an inducer of HbF. For sickle cell HbSD-Pubjab disease, the results of hydroxyurea treatment are yet to be established. A single centre study found elevated $\mathrm{HbF}$ level related to a protective effect

Jayaweera Arachchige Asela Sampath Jayaweera

Jaas820703@yahoo.com; jaasjayaweera@rjt.med.ac.lk

1 Department of Paediatrics, Teaching Hospital Anuradahapura, Anuradhapura, Sri Lanka

2 Department of Microbiology, Faculty of Medicine and Allied Sciences, Rajarata University, Saliyapura, Sri Lanka

3 Department of Biochemistry, Faculty of Medicine and Allied Sciences, Rajarata University, Saliyapura, Sri Lanka

4 Department of Pathology, Teaching Hospital Anuradahapura, Anuradhapura, Sri Lanka

5 Human Genetics Unit, University of Colombo, Colombo, Sri Lanka

6 Department of Anatomy, Faculty of Medicine, University of Colombo, Colombo, Sri Lanka following hydroxyurea treatment for sickle cell HbSDPubjab disease [3]. We describe here, our experiences with 3 HbSD-Punjab patients, 2 of whom/all 3 were treated with hydroxyurea.

A 10-year-old girl presented with having 12 episodes dyspnoea and fever where most episodes required pediatric intensive care and ventilator support (Case-1). These episodes were associated with haemoglobin counts of less than $6 \mathrm{~g} / \mathrm{dl}$, and numerous amounts of sickle cells $(90 \%)$ in the blood picture. She had been diagnosed as having sickle cell HbSD-Pubjab disease at $1 \mathrm{y}$ of age by High Performance Liquid Chromatography (Table 1). Her chest $\mathrm{x}$-ray was suggestive of sickle chest syndrome. After introducing hydroxyurea $500 \mathrm{mg}$ daily, her $\mathrm{HbF}$ level increased up to $25 \%$ and during 18 months of follow-up and she remained healthy.

A 16-year-old boy who is the elder brother of the girl in case-1 was diagnosed as having Sickle cell HbSD disease at the age of $7 \mathrm{y}$ by routine family screening (Case-2). He had two episodes of painful limping and three episodes of right sided focal seizures. Both of these episodes were associated with low haemoglobin levels $(6.5 \mathrm{~g} / \mathrm{dl})$ and $70 \%$ of sickle cells in blood picture (Table 1). X-ray of the right hip showed a vascular necrosis. After introducing hydroxyurea, $500 \mathrm{mg}$ daily, $\mathrm{HbF}$ level increased up to $25 \%$ and during 18 months of follow-up, he remained healthy.

A 22-year-old Caucasian male, drew medical attention because of incidental finding of jaundice at the age of $18 \mathrm{y}$ (Case-3). His full blood count showed Hb: $8.2 \mathrm{~g} / \mathrm{dL}$ and blood picture showed features of sickle cell disease including mild polychromasia and Howel-Jolly bodies which indicates auto splenectomy. The ultrasound examination of the abdomen showed multiple gall stones. He was not on hydroxyuria therapy. 
Table 1 Clinical manifestation and hematological parameters of patients with sickle HbSD-Punjab disease: before and after the treatment with Hydroxyurea

\begin{tabular}{|c|c|c|c|c|}
\hline Patient & $\begin{array}{l}\text { Clinical manifestation and } \\
\text { Haematological parameters }\end{array}$ & Before treatment & $\begin{array}{l}\text { After treatment with } \\
\text { hydroxyurea }\end{array}$ & $\begin{array}{l}p \text { value and comments }(p<0.05 \\
\text { taken as significant })\end{array}$ \\
\hline \multirow[t]{13}{*}{ Case 1} & $\mathrm{Hb} \%$ & $6 \mathrm{~g} / \mathrm{dL}$ & $9 \mathrm{~g} / \mathrm{dL}$ & 0.03 \\
\hline & Sickle chest syndrome & $\begin{array}{l}12 \text { episodes over } \\
10 \text { years }\end{array}$ & No episode over 18 months & \\
\hline & \multirow[t]{4}{*}{ HPLC } & $\mathrm{HbF}-14.6 \%$ & $\mathrm{HbF}-27 \%$ & 0.03 \\
\hline & & $\mathrm{HbS}-35 \%$ & $\mathrm{HbS}-24 \%$ & 0.02 \\
\hline & & $\mathrm{HbD}-49 \%$ & $\mathrm{HbD}-49 \%$ & - \\
\hline & & $\mathrm{Hb} \mathrm{A}^{\mathrm{a}}-1.4 \%$ & $\mathrm{Hb} \mathrm{A}-0 \%$ & - \\
\hline & Mean cell & $80.52 \pm 7.89 \mathrm{fl}$ & $87.90 \pm 4.69 \mathrm{fl}$ & 0.03 \\
\hline & volume $\mathrm{MCH}$ & $25.54 \pm 1.46 \mathrm{pg}$ & $28.25 \pm 1.34 \mathrm{pg}$ & 0.04 \\
\hline & $\mathrm{MCHC}$ & $30.45 \pm 1.00 \mathrm{~g} / \mathrm{dl}$ & $32.45 \pm 0.6 \mathrm{~g} / \mathrm{dl}$ & 0.04 \\
\hline & White Blood & $5.82 \pm 1.95$ & $4.82 \pm 2.95$ & $>0.05$ \\
\hline & Cells & $220 \pm 600$ & $180 \pm 300$ & 0.04 \\
\hline & Platelets & $910 \pm 256 \mathrm{U} / \mathrm{L}$ & $210 \pm 90 \mathrm{U} / \mathrm{L}$ & 0.03 \\
\hline & Lactate dehydrogenase & & & \\
\hline \multirow[t]{13}{*}{ Case 2} & $\mathrm{Hb} \%$ & $6.5 \mathrm{~g} / \mathrm{dL}$ & $9.1 \mathrm{~g} / \mathrm{dL}$ & \\
\hline & Seizures & 3 episodes & No episode & \\
\hline & Painful limping & $\begin{array}{l}2 \text { episodes over } \\
7 \text { years }\end{array}$ & No episode over 18 months & \\
\hline & HPLC & HbF- $6.7 \%$ & $\mathrm{HbF}-25 \%$ & 0.03 \\
\hline & & $\mathrm{HbS}-42.5 \%$ & $\mathrm{HbD}-44.5 \%$ & $>0.05$ \\
\hline & & $\mathrm{HbD}-45.5 \%$ & $\mathrm{HbS}-25.5 \%$ & 0.03 \\
\hline & & $\mathrm{HbA}^{\mathrm{a}}-5.3 \%$ & $\mathrm{HbA}-5 \%$ & $>0.05$ \\
\hline & $\mathrm{MCV}$ & $79.52 \pm 6.34 \mathrm{fl}$ & $86.90 \pm 4.16 \mathrm{fl}$ & 0.03 \\
\hline & $\mathrm{MCH}$ & $24.32 \pm 1.36 \mathrm{pg}$ & $28.45 \pm 1.24 \mathrm{pg}$ & 0.04 \\
\hline & $\mathrm{MCHC}$ & $30.56 \pm 0.90 \mathrm{~g} / \mathrm{dl}$ & $32.55 \pm 0.7 \mathrm{~g} / \mathrm{dl}$ & 0.04 \\
\hline & WBC & $4.32 \pm 1.95$ & $4.82 \pm 2.95$ & $>0.05$ \\
\hline & Plts & $260 \pm 700$ & $160 \pm 200$ & 0.04 \\
\hline & $\mathrm{LDH}$ & $860 \pm 205 \mathrm{U} / \mathrm{L}$ & $230 \pm 110 \mathrm{U} / \mathrm{L}$ & 0.03 \\
\hline \multirow[t]{13}{*}{$\begin{array}{c}\text { Case } \\
3^{\mathrm{b}}\end{array}$} & & First visit & $\begin{array}{l}\text { After } 18 \text { months follow up not } \\
\text { on hydroxyurea }\end{array}$ & \\
\hline & \multirow[t]{6}{*}{$\mathrm{Hb} \%$} & $8.2 \mathrm{~g} / \mathrm{dL}$ & $8.4 \mathrm{~g} / \mathrm{dL}$ & \\
\hline & & $\begin{array}{l}\text { Only one episode of } \\
\text { Jaundice. }\end{array}$ & & \\
\hline & & $\mathrm{HbF}-9 \%$ & $\mathrm{HbF}-10 \%$ & $>0.05$ \\
\hline & & $\mathrm{HbD}-45 \%$, & $\mathrm{HbD}-44.5 \%$ & $>0.05$ \\
\hline & & HbS-39.5\% & $\mathrm{HbS}-39 \%$ & $>0.05$ \\
\hline & & $\mathrm{HbA}^{\mathrm{a}}-6.5 \%$ & $\mathrm{HbA}-6.5 \%$. & $>0.05$ \\
\hline & $\mathrm{MCV}$ & $84.52 \pm 7.89 \mathrm{fl}$ & $82.90 \pm 4.69 \mathrm{fl}$ & $>0.05$ \\
\hline & $\mathrm{MCH}$ & $25.54 \pm 1.46 \mathrm{pg}$ & $25.25 \pm 1.34 \mathrm{pg}$ & $>0.05$ \\
\hline & $\mathrm{MCHC}$ & $30.45 \pm 1.00 \mathrm{~g} / \mathrm{dl}$ & $30.55 \pm 0.6 \mathrm{~g} / \mathrm{dl}$ & $>0.05$ \\
\hline & WBC & $5.82 \pm 1.95$ & $4.82 \pm 2.95$ & $>0.05$ \\
\hline & Plts & $260 \pm 600$ & $280 \pm 300$ & $>0.05$ \\
\hline & $\mathrm{LDH}$ & $410 \pm 256 \mathrm{U} / \mathrm{L}$ & $310 \pm 90 \mathrm{U} / \mathrm{L}$ & $>0.05$ \\
\hline
\end{tabular}

$H g b$ haemoglobin concentration, $M C V$ mean cell volume, $M C H$ mean cell haemoglobin, $M C H C$ mean cell haemoglobin concentration, $W B C$ white blood cells ${ }^{\mathrm{a}} 10^{9} / 1$, Plts platelets ${ }^{\mathrm{a}} 10^{9} / 1$., $L D H$ lactate dehydrogenase units/L

a All cases having HbA could be due to residual of transfusions

b Not on hydroxyurea treatment 
Many epidemiologic studies suggested that disease complications most closely linked to vaso-occlusion and blood viscosity [4]. Here, in case- 1 and case- 2 their complications were associated with vaso-occlusion. When the total $\mathrm{HbF}$ concentration is near $25-30 \%$, it is possible for the number of "protected cells" to approach $70 \%$ which can suppress the clinical symptoms [5]. Since case-3 was an incidental finding and was asymptomatic we haven't introduced hydroxyurea. Further, case-1 showed most severe clinical presentation and case- 2 was milder than case- 1 while case- 3 had the least severity. This indicates the phenotypic heterogeneity and the reason behind would be having gene-gene interactions.

These 3 cases highlight that clinical manifestations showing mild to severe form of HbS/D-Punjab disease which indicate the phenotypic heterogeneity. Also, use of hydroxyurea which is a $\mathrm{HbF}$ inducer suppresses the severity of clinical manifestations of the HbS/D-Punjab disease which is a rare form of sickle cell anemia.

\section{Compliance with Ethical Standards}

Conflict of interest The authors declare that there is no conflict of interest regarding the publication of this paper.
Ethical Approval Was obtained from Ethics Review Committee, Faculty of Medicine and Allied Sciences, Rajarata University Saliyapura, Sri Lanka.

Informed Consent Informed consent was obtained from guardians of all individual participants included in the study.

\section{References}

1. Vella F, Lehmann H (1974) Haemoglobin D Punjab (D Los Angeles). J Med Genet 11:341-342

2. Barbara JB (2001) Sickle SS disease, haemoglobinopathy diagnosis, 2nd edn. Wiley-Blackwell Science, Oxford, pp 275-296

3. Patel S, Purohit P, Mashon RS, Dehury S, Meher S, Sahoo S et al (2014) The effect of hydroxyurea on compound heterozygotes for sickle cell-hemoglobin D-Punjab-a single centre experience in eastern India. Pediatr Blood Cancer 61(8):1341-1346. doi:10. $1002 /$ pbc. 25004

4. Steinberg MH (2009) Sickle cell SS. In: Steinberg MH, Forget BG, Higgset DR (eds) Disorders of hemoglobin: genetics, pathophysiology, clinical management, 2nd edn. Cambridge University Press, Cambridge

5. Alsultan A, Alabdulaali MK, Griffin PJ, AlSuliman AM, Ghabbour HA, Sebastiani P et al (2014) Sickle cell disease in Saudi Arabia: the phenotype in adults with the Arab-Indian haplotype is not benign. Br J Haematol 64(4):597-604. doi:10.1111/bjh.12650 